A RCHIWA, BIBLIOTEKI

I MUZEA KOŚCIELNE 111 (2019)

https://doi.org.10.31743/abmk.2019.111.04

KS. PIOTR GÓRECKI* - GLIWICE

\title{
KS. JOHANNESA CHRZĄSZCZA ZAPISKI O I WOJNIE ŚWIATOWEJ. SYLWETKA GÓRNOŚLĄSKIEGO HISTORYKA W 90. ROCZNICE ŚMIERCI
}

\section{Streszczenie}

Przypadająca w 2018 roku 90. rocznica śmierci ks. Johannesa Chrząszcza jest dobrą okazją, aby przybliżyć szerszemu gronu czytelniczemu sylwetkę tegoż górnośląskiego kapłana. Ks. Piotr Górecki w swoim artykule przybliża nie tylko sylwetkę ks. J. Chrząszcza, wspominając o najważniejszych wydarzeniach $\mathrm{z}$ jego kapłańskiego życia i prezentując spuściznę jego prac naukowych, liczącą 172 pozycje, głównie z historii Górnego Śląska. Na kanwie 100. rocznicy zakończenia I wojny światowej snuje przede wszystkim refleksję dotyczącą postawy tegoż śląskiego kapłana wobec władzy świeckiej. Źródłem badawczym stały się pozostawione przez ks. J. Chrząszcza zapiski kronikarskie, jakie zamieścił w książce o dziejach dwóch górnośląskich miejscowości - Toszka i Pyskowic. Lektura zapisków starszego już wówczas kapłana odkrywa przed nami ogromne dylematy, z jakimi borykał się on i współcześni mu duszpasterze. Wydaje się, że jego lojalna postawa miała na celu nie dopuścić do jakichkolwiek przewrotów i rewolt społecznych, nawet za cenę bezkompromisowej wierności względem władzy świeckiej i zachowania lansowanego przez wieki „sojuszu ołtarza z tronem”. Taka postawa cechowała także liczne grono innych duszpasterzy w okupowanych przez zaborców różnych częściach Polski. Można postawić tezę, że zarówno ks. J. Chrząszcz, jak i współcześni mu ludzie Kościoła byli swoistego rodzaju epigonami mijającej epoki. Nie zauważyli oni jutrzenki narodzin nowych czasów i nowego porządku, która przyniosła Polsce odrodzenie, a ziemi śląskiej nową nadzieję. W ocenie potomnych taka postawa ks. J. Chrząszcza była wystarczającym powodem do tego, aby nie uwzględniać

* Ks. Piotr Górecki - dr hab. historii Kościoła; adiunkt w katedrze Historii Kościoła i Patrologii Wydziału Teologicznego UO; kierownik Archiwum Kurii Diecezjalnej w Gliwicach; e-mail: pgorecki@uni.opole.pl

https://orcid.org/0000-0002-6052-3968 
jego osoby w badaniach historycznych. A szkoda, ponieważ znajomość jego dorobku naukowego może dopomóc w lepszym zrozumieniu dziejów Śląska, jak i uświadomienia sobie bogatej spuścizny wielokulturowości, która przez wieki cechowała Ślązaków.

Słowa kluczowe: ks. Johannes (Jan) Chrząszcz; historia Kościoła na Śląsku; Górny Śląsk; I wojna światowa

\section{Wstęp}

W historii lokalnych społeczności nie do przeceniania są takie osoby, które sporą część swojego życia poświęcili badaniu ich przeszłości. Wielu z nich pozostawiło nam, potomnym, tak cenne zapiski, że ich treść w ferworze zamętów historii stanowi niejednokrotnie wyłączne źródło historyczne dotyczące lokalnej przeszłości. W 2017 roku samorządowe społeczności lokalne: Gliwic, Pyskowic i Toszka, przy współpracy Wydziału Teologicznego Uniwersytetu Opolskiego, Muzeum Miejskiego w Gliwicach i Archiwum Państwowego w Katowicach, zainaugurowały Rok ks. Johannesa Chrzaszcza - wybitnego badacza dziejów Kościoła katolickiego na Śląsku. Okazją była przypadająca w 2017 roku 160. rocznica urodzin, a w 2018 roku 90. rocznica jego śmierci. W tym czasie zorganizowano cykle odczytów i konferencji naukowych, poświęconych twórczości pisarskiej i działalności społeczno-kulturowej wieloletniego pyskowickiego proboszcza. Wydarzeniem finalnym był panel dyskusyjny, który miał miejsce w Muzeum Miejskim w Gliwicach 11 maja 2018 roku, podsumowujący wszystkie wydarzenia mijającego jubileuszu. W czasie tych spotkań niejednokrotnie stawiano pytanie, czy w przypadku polskiej historiografii możemy mówić o ks. Johannesie Chrząszczu, skoro politycznie bliższa mu była opcja proniemiecka? Taką postawę zarzucano mu w przypadku pozostawionych przez niego zapisków z okresu I wojny światowej i późniejszego zrywu niepodległościowego na Górnym Śląsku. Chciałbym, aby niniejszy tekst był próbą odpowiedzi na stawiane wówczas zarzuty, na jaką wówczas nikt z historyków się nie silił. Wydaje mi się to tym bardziej słuszne, ponieważ osoba ks. Chrząszcza jest nadal mało znana w polskim środowisku historyków. Aż do 1989 roku jedynie nieliczni badacze wskazywali na ogromna wartość pozostawionych przez niego dzieł, kluczowych w zgłębianiu historii Górnego Śląska, także tej XIX i XX-wiecznej ${ }^{1}$. Po zarysowaniu sylwetki ks. Johannesa Chrząszcza, szczególnie jego działalności duszpasterskiej i nauko-

\footnotetext{
${ }^{1} \mathrm{Na}$ gruncie polskim jego osobą do wybuchu II wojny światowej zajmowali się jedynie bł. ks. Emil Szramek (zm. w 1942 roku) i Wincenty Ogrodziński (zm. w 1945 roku). Zob. E. Szramek, Ks. dr Jan Chrząszcz. Wspomnienie pośmiertne, „Roczniki Towarzystwa Przyjaciół Nauk na Śląsku”, 1 (1929) s. 258-261; W. Ogrodziński, Chrzaszcz Jan, w: Polski Słownik Biograficzny, red. W. Konopczyński, t. 3, Kraków 1937, s. 476; W. Ogrodziński, Dzieje piśmiennictwa ślaskiego, do druku przyg. L. Brożek, Z. Hierowski, Katowice 1965, s. 206-207, 292, 320, 384. Kolejnymi historykami, którzy na gruncie polskojęzycznej literatury historyczno-teologicznej wskazywali na jego osobę, byli ks. Kazimierz Dola, Halina Kowalczyk i ks. Józef Mandziuk. Zob. K. Dola, Chrząszcz Jan, w: Encyklopedia katolicka, red. R. Łukaszyk, Lublin 1979, t. 3, k. 346; H. Kowalczyk, Chrzaszcz Jan (1857-1928), w: Stownik biograficzny katolickiego duchowieństwa śląskiego XIX i XX wieku, red. M. Pater, Katowice 1996, s. 68-69; J. Mandziuk, Chrzaszcz Jan, w: Stownik polskich
} 
wej, zostaną poddane analizie jego zapiski kronikarskie, jakie zamieścił w drugim wydaniu monografii o dziejach Pyskowic i Toszka - dwóch miejscowości na terenie ziemi gliwickiej na Górnym Śląsku². Ponieważ ów zapis jest bardzo bogaty, postaram się ograniczyć jedynie do tekstów mówiących wprost o wydarzeniach z tzw. „wielkiej wojny”: przygotowaniach do niej, przebiegu działań wojennych i ówczesnych postaw górnośląskiego społeczeństwa. Dotychczas bowiem nieliczni, wzorem ks. Alfonsa Nowacka - dyrektora ówczesnego Archiwum Archidiecezjalnego we Wrocławiu - wskazywali również i na tę stronę - ważnej ich zdaniem - pisarskiej działalności ${ }^{3}$. Aby uniknąć błędu ahistoryzmu, moje spostrzeżenia oprę na dostępnych dokumentach i zarządzeniach kościelnych, jakie władza duchowna wydawała ówcześnie dla podległego im duchowieństwa ${ }^{4}$. Chciałbym w ten sposób udowodnić, że hipotezy mówiące o stronniczych postawach ks. Chrząszcza są błędne i nie mogą wypaczać całokształtu jego bogatej działalności. Często przyrównuje się ją z rozmiarami działalności ks. Augustina Weltzla (zm. w 1897 roku) - określanego przez współczesnych mu „śląskim Tacytem”.

\section{Krótka biografia ks. Chrząszcza}

Ks. Johannes Chrząszcz urodził się 27 kwietnia 1857 roku w chłopskiej rodzinie Josefa Chrząszcza i Marianny z domu Hupka w Mionowie k. Głogówka. Szkołę podstawową ukończył w Wierzchu. Duży wpływ na chłopca miał sąsiad Chrząszczów, chłop Ignacy Dziadek - były poseł do Landtagu w Berlinie, właściciel sporej biblioteki, autor kilku bajek i sztuk dla dzieci. Mały Johannes lubił słuchać jego opowieści, wzbudzając w sobie pasję do historii. Na duże zdolności

teologów katolickich 1918-1981, red. L. Grzebień, t. 5, Warszawa 1983, s. 216-221. Były to przypadki odosobnione i dopiero po przemianach 1989 roku można było przystąpić do bardziej wnikliwszych badań.

${ }^{2}$ Pierwsze wydanie monografii dziejów Pyskowic i Toszka ukazało się w 1900 roku, a jej drugie wydanie w 1927 roku. Zob. J. Chrząszcz, Geschichte der Städte Peiskretscham und Tost sowie des Toster Kreises in Oberschlesien, Peiskretscham 1900; Peiskretscham 19272. To właśnie drugie wydanie tegoż dzieła, którego zapis po 1900 roku przybiera charakter pisanego przez ks. J. Chrząszcza pamiętnika - swoistej kroniki wydarzeń - stanowi podstawę moich badań. O doniosłości tegoż dzieła dla lokalnych społeczności może świadczyć fakt jego dwukrotnego wydania w języku polskim. Zob. J. Chrząszcz, Historia miast Pyskowice i Toszek, wyd. 2, Pyskowice 1994; Gliwice 2009.

${ }^{3}$ Zob. A. Nowack, Dem Andenken an Dr. Johannes Chrzaszcz, „Der Oberschlesier”, 13 (1931) nr 5, s. 284, 286. Por. A. Nowack, Lebensbilder schlesischer Priester, Breslau 1939, s. 145-153; J. Giela, Biographisch-bibliographische Studien zu dem oberschlesischen Pfarrer und Historiker Johannes Chrzaszcz, „Oberschlesisches Jahrbuch”, 16-17 (2000/2001) s. 91-128; S. Rosenbaum (oprac.), „Doctor inefabilis”. Ksiadz Johannes Chrzaszcz i jego miejsce w spuściźnie kulturowej Górnego Śląska, w: J. Chrzaszcz, ,, Meminisse iuvat”. Wybór pism, Gliwice 2018, s. 24-27.

${ }^{4}$ Źródłem dla badań porównawczych stały się zarządzenia Książęco-Biskupiego Wikariatu Generalnego we Wrocławiu: Verordnungen des Fürstbischöflichen General-Vikariat-Amtes zu Breslau (dalej: Verordnungen). Od 15 sierpnia 1914 roku do końca grudnia 1918 roku (czyli do czasu wybuchu rewolucji w Niemczech) ukazało się w sumie 107 numerów informatora (od numeru 543 z 15 sierpnia 1914 roku do numeru 650 z 20 grudnia 1918 roku). W 1915 roku zaprzestano numeracji stron, posługując się jedynie numeracją ciągłą publikowanych zarządzeń. 
chłopca zwrócił uwagę inspektor szkolny Kadlubetz, który przy pomocy ks. proboszcza Massorza przekonał matkę, aby wysłać dziecko do gimnazjum, a później na studia ${ }^{5}$. Tak też się stało i młody Johannes w 1871 roku rozpoczął naukę w gimnazjum w Głubczycach, a od 1873 roku w Gimnazjum św. Macieja (St. MatthiasGymnasium) we Wrocławiu. W tym czasie wybuchł otwarty konflikt na linii państwo - Kościół, zwany Kulturkampfem. Ponieważ władze zamknęły Gimnazjum św. Macieja, młody Johannes kontynuował naukę w państwowym gimnazjum w Opolu, gdzie w 1877 roku złożył egzaminy maturalne. Ponownie wrócił do Wrocławia i rozpoczął trzyletnie studia teologiczne na tamtejszym uniwersytecie. Kiedy władze państwowe i tym razem zamknęły kierunek na studiach, seminarzysta udał się w 1880 roku do Pragi, gdzie 15 lipca 1881 roku w katedrze św. Wita otrzymał święcenia kapłańskie z rąk biskupa pomocniczego Karela Pruchy ${ }^{6}$.

Nie posiadając żadnego dekretu, ks. J. Chrząszcz był początkowo kapelanem zamkowym i prywatnym guwernerem u hrabiego Strachwitza w Chróścinie Opolskiej. Ponieważ parafia nie była w tamtym czasie obsadzona, pełnił on także przy tamtejszym kościele posługę duszpasterską. Po załagodzeniu antykościelnego kursu Kulturkampfu do parafii powrócił proboszcz, a ks. J. Chrząszcz, bez dekretu, udał się do Rudy, gdzie przez dwa lata wspierał w duszpasterstwie ks. Teofila Schöneicha, pełniącego dodatkowo obowiązki tymczasowego administratora w Biskupicach i noszącego się z zamiarem budowy kościoła w liczącym 15 tys. mieszkańców Zaborzu 7 . W latach 1883-1890 pracował na stanowisku katechety i nauczyciela języka polskiego w Królewskim Gimnazjum w Gliwicach przy kościele poreformackim (obecnie redemptorystów). W tym czasie napisał pracę doktorską z teologii zatytułowaną: De Evangelio secundum Haebreos, uzyskując doktorat w październiku 1888 roku$^{8}$.

W listopadzie 1890 roku otrzymał dekret na proboszcza parafii św. Mikołaja w Pyskowicach, w której przyszło mu posługiwać przez kolejnych 37 lat. W kwietniu 1891 roku zrezygnował z posady nauczyciela, niemniej jednak do końca swojego życia wspierał działalność edukacyjną, opiekując się młodzieńcami z seminarium nauczycielskiego w Pyskowicach oraz przyczyniając się do wybudowania w 1903 roku w Gliwicach Konwiktu św. Józefa dla 150 chłopców9. Jako proboszcz patronował gruntownemu remontowi kościoła, plebanii i budynków gospodarczych. Wspierał działalność charytatywną, założył liczne stowarzyszenia i organizacje społeczno-kulturalne, angażował się w dokształcanie rolników i wspomagał rozwój miejscowego rzemiosła. Zaangażowany w życie polityczne w 1907 roku z ramienia partii Centrum kandydował do Reichstagu,

${ }^{5}$ Zob. Nowack, Dem Andenken an Dr. Johannes Chrzaszcz, s. 281.

${ }^{6}$ Tamże, s. 282. Por. Nowack, Lebensbilder schlesischer Priester, s. 146.

${ }^{7}$ Zob. Mandziuk, Chrzaszcz Jan, s. 216.

${ }^{8}$ Był to pierwszy doktorat z teologii katolickiej na Uniwersytecie Wrocławskim po 25-letniej przerwie. Zob. Ogrodziński, Chrząszcz Jan, s. 476.

${ }^{9}$ Por. Nowack, Lebensbilder schlesischer Priester, s. 148-149. 
przegrywając nieznacznie wybory w drugiej turze z ks. proboszczem Jankowskim z opcji propolskiej. Przez wiele lat pełnił funkcję członka Rady Miasta Pyskowice, otrzymując po latach godność honorowego obywatela miasta ${ }^{10}$.

Ks. J. Chrząszcz był poliglotą. Dobrze znał języki: niemiecki, polski, czeski, łaciński, grecki i hebrajski. Za jego wszechstronne zaangażowanie i udział w życiu społeczno-religijnym władze kościelne uhonorowały go godnością dziekana dekanatu pyskowickiego i radcy duchownego. W październiku 1927 roku przeszedł zawał serca. Postępującej chorobie towarzyszyła ostra niewydolność nerek. Odszedł po nagrodę do Pana 26 lutego 1928 roku. Jego ciało złożono w grobie na cmentarzu przy kaplicy św. Stanisława w Pyskowicach 1 marca 1928 roku $^{11}$.

\section{Działalność naukowa i spuścizna pisarska}

Ks. Johannes Chrząszcz jest znany najbardziej ze swojego zamiłowania do historii. Na kanwie panującej wówczas w historiografii erudycyjnej metody źródłoznawczej podejmował badania nad lokalną historią, rzetelnie opracowując dostępne mu archiwalia różnej proweniencji. Jego osiągnięcia były tak znaczące, że Uniwersytet Wrocławski kilkakrotnie proponował ,wiejskiemu proboszczowi” jak sam siebie określał - prowadzenie wykładów. W 1904 roku z udziałem ks. J. Chrząszcza powołano do życia Górnośląskie Towarzystwo Historyczne (Oberschleisischer Geschichtsverein) z siedzibą w Opolu, które propagowało wiedzę o przeszłości Śląska, wydając periodyk naukowy: "Oberschleisische Heimat. Zeitschrift des Oberschlesischen Geschichtsvereins”. Ks. J. Chrząszcz piastował początkowo stanowisko zastępcy redaktora naczelnego czasopisma, a w latach 1913-1927 stanowisko redaktora naczelnego, pełniąc równocześnie funkcję prezesa towarzystwa ${ }^{12}$. W 1905 roku, razem z prawnikiem Arthurem Schillerem i przy wydatnym wsparciu materialnym hrabiego Franza von Ballestrema, założył Muzeum Górnośląskie w Gliwicach (Oberschlesisches Museum für Kunst und Kunstgewerbe) i opracował jego statut. Przez całe swoje życie pisał książki i artykuły naukowe dotyczące historii lokalnych społeczności na podstawie dostępnych mu źródeł. Jego dorobek naukowy liczy dokładnie 172 pozycje ${ }^{13}$. W liczbie tej są rzetelnie opracowane historie górnośląskich miast: Prudnika, Białej Prudnickiej, Krapkowic, Pyskowic i Toszka oraz rodzinnej miejscowości: Wierzchu. Ponadto ks. J. Chrząszcz opisał dzieje wielu parafii, kościołów i klasztorów. Artykuły naukowe wydawał w języku niemieckim i publikował w czasopismach: „Oberschleisische Heimat”, „Zeitschrift des Vereins für Geschichte und Altertum Schlesiens”, „Oberschlesien” i „Schlesische Pastorallblatt”. Materiały do badań

\footnotetext{
${ }^{10}$ Por. P. Górecki, Dziewiętnasto- $i$ dwudziestowieczne wydarzenia na Górnym Ślasku w twórczości pisarskiej ks. Johannesa Chrzaszcza. Wprowadzenie do drugiego polskiego wydania książki „Historia miast Pyskowice i Toszek”, w: J. Chrząszcz, Historia miast Pyskowice i Toszek, Gliwice 2009, wyd. 2, s. 9-11.

${ }^{11}$ Zob. Nowack, Dem Andenken an Dr. Johannes Chrzaszcz, s. 288; Nowack, Lebensbilder schlesischer Priester, s. 153.

${ }^{12}$ Zob. Nowack, Dem Andenken an Dr. Johannes Chrzaszcz, s. 285.

${ }^{13}$ Zob. Rosenbaum, Bibliografia prac Johannesa Chrzaszcza, s. 42-55. Por. Szramek, Ks. $d r$ Jan Chrzaszcz, s. 258-261; Mandziuk, Chrzaszcz Jan, s. 217-221.
} 
czerpał nie tylko z archiwów, lecz także z codziennej prasy oraz podań i opowieści mieszkańców. Cenił księgi metrykalne jako bezcenne źródło w badaniach naukowych. W języku polskim wydawał modlitewniki i broszury o charakterze popularno-naukowym, skierowane do szerszego kręgu odbiorców, głównie prostych wiernych. Jego najbardziej popularnym dziełem była historia Kościoła na Śląsku: Kirchengeschichte Schlesiens für Schule und Haus, którą wydał w 1908 roku. Z pozycji tej korzystano w śląskich gimnazjach katolickich w ramach nauki religii w ostatnich klasach, a także chętnie czytano ją w domach. Nie obyło się jednak w tymże przypadku bez surowej krytyki. Profesor Lambert Schulte napisał na temat jego książki recenzję liczącą 18 stron, w której wytknął pyskowickiemu proboszczowi wiele niedociagnięć ${ }^{14}$. Drugim, najbardziej poczytnym dziełem ks. Chrząszcza była historia miast Pyskowic i Toszka. Blisko czterdziestoletni pobyt proboszcza w pyskowickiej parafii przyniósł wiele zmian na scenie politycznej i gospodarczej, stąd też trzeba było raz jeszcze pochylić się nad raz już napisanym dziełem. Ks. J. Chrząszcz jak wytrawny kronikarz wkomponował do drugiego wydania książki liczne wspomnienia i poczynione przez lata zapiski. Dodatkowo zlecił Franzowi Tschauderowi opracowanie tematyki związanej z gospodarczo-społecznym stanem ówczesnych Pyskowic, a Richarda Kosubka poprosił o napisanie najnowszych dziejów Toszka. Niezwykle interesujący jest kronikarski zapis ks. J. Chrząszcza, będący swoistego rodzaju komentarzem do wydarzeń ogólnoświatowych i śląskich w okresie I wojny światowej oraz jej bezpośrednich następstw. Tymże też zapiskom pragnę poświęcić dalszą część mojej pracy, poddając je gruntownej analizie.

\section{Lojalny obywatel państwa i posłuszny sługa Kościoła}

Pozostawiony przez ks. J. Chrząszcza zapis kronikarski jest w zasadzie typowy dla ówczesnych pamiętników ludzi tamtego czasu. Na kanwie wydarzeń światowych pyskowicki proboszcz snuje refleksję historyczną na podstawie dostępnych mu materiałów: wydawaną prasę codzienną, tygodniki, ogłoszenia policji czy też nadsyłane do parafii zarządzenia z wikariatu generalnego we Wrocławiu. To głównie dzięki tymże gazetom i okólnikom historyk zdobywał wiedzę o wydarzeniach światowych i toczonym konflikcie wojennym między wielkimi mocarstwami.

Jako obywatel kajzerowskich Niemiec ks. J. Chrząszcz był człowiekiem na wskroś lojalnym. Przecież autorytet władzy „,pochodził od samego Boga”. Takie również wykształcenie otrzymał na etapie szkolnym i na uniwersyteckich studiach. Sam również wyznawał zasadę, jaką za jednym z historyków przyswoił sobie na studiach, że ,wraz z przejściem Śląska pod panowanie królów pruskich w krainie tej zagościły sprawiedliwość, porządek i pokój. Szczególnie kultura Górnego Śląska przeżyła nienotowany dotąd rozwój”. Nie omieszkał jednak dodać, że zanim to się stało, przez śląskie ziemie przetoczyły się trzy krwawe wojny, które Ślązakom dostarczyły wielu cierpieńn ${ }^{15}$. Jako historyk żywił przekonanie, że

\footnotetext{
${ }^{14}$ Por. Nowack, Dem Andenken an Dr. Johannes Chrzaszcz, s. 286.

${ }^{15}$ Chrząszcz, Historia miast Pyskowice i Toszek, s. 26.
} 
„dzięki licznym ustawom królewskim, korzystnym zarówno dla ludności miejskiej, jak i wiejskiej, zaczął wzrastać ogólny dobrobyt, a także przedsiębiorczość ludności" ${ }^{16}$. Ten dobrobyt był na początku dwudziestego stulecia zauważalny. Kto mógł przewidzieć, że „wielka wojna” zburzy porządek społeczny, który trwał w Europie od wieków.

Kiedy po Wiośnie Ludów 1848 roku nastąpiło ożywienie ducha narodowościowego, również w sercach wielu mieszkańców Górnego Śląska zrodziła się tęsknota za wskrzeszeniem niepodległego państwa polskiego. Ks. J. Chrząszcz nie ukrywał, że większość mieszkańców powiatu toszeckiego, w którym żył i pracował jako kapłan, nie licząc drobnych wyjątków, była pochodzenia słowiańskiego. „Polski język, jako cecha wyróżniająca, oraz słowiańskie nazewnictwo miejscowości występują [tu] jeszcze do dzisiaj” - pisał ks. J. Chrząszcz w swojej monografii ${ }^{17}$. Ale na Sląsku od pokoleń mieszkały także rodziny ducha niemieckiego. To dzięki nim „,począł rozkwitać kraj, zapełniany pracowitymi mieszkańcami”. Ks. J. Chrząszcz słusznie zauważał, że z biegiem wieków „nastąpiło stopniowe wymieszanie starej ludności słowiańskiej z niemieckimi osadnikami”"18. Dlatego z niepokojem śledził każde nowe wybory, które wśród Ślązaków wyzwalały emocje. Jednakowo nie ufał nacjonalistycznym partiom niemieckim, jak i rodzącym się nastrojom wśród tych Ślązaków, którzy coraz odważniej mówili o „,wskrzeszeniu wielkiej Polski"19.

W kapłańskim gronie nie brakowało takich duszpasterzy, którzy będąc świadkami historycznych wydarzeń, pragnęli ratować ducha wielokulturowości tej ziemi i wspólnej koegzystencji. Taka postawa cechowała także ks. J. Chrząszcza. Wydaje się, że był on ślepo przywiązany do archaicznej zasady sojuszu ołtarza $\mathrm{z}$ tronem jako najlepszej metody troski o dusze ludzkie, a jednocześnie wzorcowej postawy prospołecznej. Wyraźną tego oznaką była praktyka odprawiania w śląskich parafiach nabożeństw w języku niemieckim i w języku polskim. W wielu górnośląskich parafiach, także w Pyskowicach, o wiele więcej wiernych uczestniczyło w nabożeństwach polskojęzycznych. W dni targowe na polskie nabożeństwa przyjeżdżali do Pyskowic także mieszkańcy z okolicznych wiosek. Ks. J. Chrząszcz nie traktował polskich nabożeństw za bardziej uprzywilejowane. Ponieważ więcej ludzi do końca I wojny światowej wybierało właśnie te nabożeństwa, dlatego termin ich odprawiania wyznaczały godziny, które cieszyły się większą frekwencją ${ }^{20}$.

Trzeba pamiętać, że ani w Niemczech, ani w jakichkolwiek innych krajach nie było mowy o jakimkolwiek przeciwstawieniu się legalnej władzy. Kościół katolicki w Niemczech i na Śląsku pamiętał jeszcze rany wywołane nienawistną polityką Kulturkampfu. Państwo niemieckie, prowadząc w latach 70. i 80. XIX wieku walkę o kulturę z Kościołem katolickim, postrzegało go jako twór nieposłuszny władzy i jątrzący w stosunki ogólnospołeczne. Dawny bunt duszpasterzy wzglę-

\footnotetext{
16 Tamże, s. 102.

17 Tamże, s. 95.

18 Tamże, s. 28-29.

19 Tamże, s. 153-155.

${ }^{20}$ Tamże, s. 155.
} 
dem zarządzeń ekipy rządzącej przyniósł ogromne straty: setki nieobsadzonych parafii i pozbawione sakramentów rzesze wiernych. Ponieważ wielu katolików umierało bez kapłana, determinowało to duchowieństwo do ugody, nawet za cenę wielu ustępstw. Po latach takiej bezsensownej wojny Kościół chciał przekonać państwo o swojej użyteczności, a w taki sposób niejako na początku XX wieku wyjść z postawy nieufności i izolacji. Dzięki zręcznej polityce pasterzy Kościoła na Śląsku: kardynała Georga Koppa ${ }^{21}$ i jego następcy - biskupa Adolfa Bertrama $^{22}$, również późniejszego kardynała, wierni mogli swobodnie wyznawać swoją wiarę i jako wolni obywatele korzystali ze wszystkich praw i przywilejów przynależnych obywatelom jednego państwa. A przecież jeszcze na początku XIX wieku w pruskim, czyli protestanckim, państwie tak nie było. Biskupi drogą pertraktacji starali się zapewnić swobodną działalność Kościoła. Chcieli tym samym usunąć stygmat narodowej „nieprzydatności katolików”. W chwili wybuchu I wojny światowej postrzegali Rzeszę jako kraj zmuszony do wojny obronnej, stąd nie wyrażali wątpliwości co do jej usprawiedliwionego prowadzenia ${ }^{23}$.

\section{Sytuacja sprzed 1914 r. w zapiskach ks. Chrząszeza}

Czerwcowy zamach w Sarajewie (28 czerwca 1914 roku) oraz gwałtowny przebieg kryzysu lipcowego doprowadziły do wybuchu I wojny światowej. Nigdy dotąd $\mathrm{w}$ wojnie nie wzięło udział tak wiele narodów, a działania wojenne objęły swoim zasięgiem nie tylko Europę. Ks. J. Chrząszcz jak wytrawny polityk wiedział, że była to konsekwencja burzliwej polityki europejskich imperiów, którym było coraz ciaśniej na świecie. W przypadku dziejów Toszka i Pyskowic na łamach swojej książki zamieszczał informacje, które jego zdaniem zapowiadały nadejście ogólnoświatowego konfliktu.

Preludium wojny zapowiadał przeprowadzony zamach na króla Serbów Aleksandra i jego żonę Dragę w 1903 roku: „Kto jednak wówczas mógł przypuszczać,

${ }^{21}$ Georg Kopp (1837-1914) - książę-biskup wrocławski w latach 1887-1914, członek pruskiej rady państwa, pruskiej izby panów i austriackiej izby panów. Był jednym z głównych autorów normalizacji stosunków na linii państwo-Kościół po kryzysie wywołanym Kulturkampfem. Czynnie angażował się w sprawy społeczne i szkolnictwo. Wspierał katolicki ruch robotniczy, akcentując jego chrześcijańskie korzenie oraz łączność z Kościołem, co miało być przeciwwagą względem budzących się ruchów socjalistycznych. Papież Leon XIII 16 stycznia 1893 roku mianował go kardynałem. Zob. J. Mandziuk, Historia Kościoła katolickiego na Śląsku, t. 3: Czasy nowożytne, cz. 3: 1887-1914, Warszawa 2009, s. 29-49.

${ }^{22}$ Adolf Bertram (1859-1945) - biskup diecezji wrocławskiej w latach 1914-1945, którą w 1929 roku podniesiono do rangi archidiecezji. W 1916 roku mianowany kardynałem in pectore. Nominację kardynalską oficjalnie ogłoszono po zakończeniu wojny w 1919 roku. Od 1920 roku był przewodniczącym niemieckiej konferencji biskupów mającej swoją siedzibę w Fuldzie. Zob. M. Piela, Ksiażę kardynat dr Adolf Johannes Bertram jako przewodniczący Konferencji Episkopatu Niemiec (Fuldajskiej Konferencji Biskupów) w latach 1920-1945, cz. 1: Do końca istnienia Republiki Weimarskiej, Wrocław 2013.

${ }^{23}$ Zob. A. Bertram, De vita clericali sacerdotum auctoritate militari conscriptorum „Verordnungen”, (1916) nr 580 (1.03.1916 r.), s. 28-29; S. Hinkel, Adolf Kardinal Bertram. Kirchenpolitik in Kaiserreich und Weimarer Republik (Veröffentlichungen der Kommission für Zeitgeschichte, seria B: Forschungen, t. 117), Paderborn-München-Wien-Zürich 2007, s. 95. 
że ów haniebny czyn w Belgradzie jest pierwszą oznaką zbliżającej się wojny światowej"24? Co prawda utworzono rząd ludowy, ale pokoju po tym rozlewie krwi nie było. W sąsiedniej Rosji panowały poważne niepokoje, w Serbii chwiał się tron króla Piotra, trzęsienie ziemi 1908 roku zniszczyło całkowicie miasto Messynę na Sycylii. W 1910 roku ks. J. Chrząszcz pisał: „Coraz gwałtowniej rozwijały się tendencje rewolucyjne. Rzadko dotąd w takim stopniu mogły się rozrastać szyderstwa i wrogość w odniesieniu do tronu i ołtarza"25. W 1913 roku obchodzono trzy jubileusze: 100-lecie wojen wyzwoleńczych, 25-lecie koronacji cesarza Wilhelma II oraz 1600-lecie edyktu mediolańskiego. Z tej okazji ks. J. Chrząszcz, 10 marca tegoż roku, odprawił uroczyste nabożeństwo dziękczynne, po którym w pobliżu groty lurdzkiej zasadził drzewo dębowe. „U nas panował spokój, podczas gdy wokół Niemiec, a także w Portugalii, na Bałkanach i w innych krajach szalały wojny i rozruchy. Doprawdy, cesarz Wilhelm był pokojowym władcą" snuł smutną refleksję pyskowicki proboszcz ${ }^{26}$. Podobnie o samym cesarzu wyrażał się biskup diecezji wrocławskiej Adolf Bertram. W czasie trwającej już wojny ukazywał wiernym cesarza jako ojca narodu, zmuszonego do prowadzenia wojny w obronie ojczyzny: „Idziemy na wojnę ze świadomością, że walczymy za króla, który wyruszył w prawdziwie chrześcijańskim usposobieniu"27. Biskup prosił o modlitwę w jego intencji i zapewniał o miłości i przywiązaniu katolików względem swojego monarchy ${ }^{28}$. W jednym $\mathrm{z}$ listów pasterskich pisał:

Gdyby to był zgubny żar ziemskiego egoizmu i chciwość podbojów, które pochłaniają te ofiary, wtedy akt ofiarniczy byłby nawet okrucieństwem przed Panem. Natomiast ofiary walki w posłuszeństwie wobec Boga, w obronie ojczyzny i chrześcijańskiej kultury... niosą w sobie święte poświęcenie się ${ }^{29}$.

W przeciwieństwie do swojego pasterza, lojalnego względem cesarza, ks. J. Chrząszcz był nieco bardziej ostrożny w ocenach. Z przerażeniem pisał w momencie wybuchu wojny:

Jedni wierzyli [zamieszczonym w gazetach informacjom], inni drwili: „Co, wojna? Kto ma tyle pieniędzy, aby prowadzić wojnę”? (...) W niedzielę, 2 sierpnia, wielu księży wygłosiło kazanie na temat wojny. W Pyskowicach o wojnie w kazaniu nie mówiono, aby nie wzburzać wiernych ${ }^{30}$.

Ostrożność ta okazała się zbędna, bowiem nazajutrz całe miasto wrzało od zamieszczonych w gazetach informacjach: „Stan wojenny dla Rzeszy! Niebezpieczeństwo wojny! Rosja prowadzi nadal mobilizację"31.

${ }^{24}$ Zob. Chrząszcz, Historia miast Pyskowice i Toszek, s. 153.

${ }^{25}$ Tamże, s. 165.

${ }^{26}$ Tamże, s. 170.

${ }^{27}$ Cyt. za: Piela, Książe kardynat dr Adolf Johannes Bertram, s. 163.

${ }^{28}$ Zob. Bertram, Kirchliche Begehung des Geburtstages des Kaisers, „Verordnungen” 1915, nr 554 (18.01.1915 r.), s. 9.

${ }^{29}$ Tenże, Kreuzeskraft und Kreuzeslehren in der Kriegszeit (Fastenhirtenbrief), „Verordnungen”, (1916) nr 576 (2.02.1916 r.), s. 55.

${ }^{30}$ Zob. Chrząszcz, Historia miast Pyskowice i Toszek, s. 173.

${ }^{31}$ Tamże. 


\section{Nadzieja na szybkie zakończenie wojny}

Działania wojenne szybko objęły Belgię i Francję z jednej strony frontu i Rosję $-z$ drugiej strony. W środę, 5 sierpnia, o godz. 6 rano ks. J. Chrząszcz sprawował okolicznościowe nabożeństwo z kazaniem: „Kościół był przepełniony, szloch i bolesne westchnienia wstrząsały świątynią"32. W piątek wieczorem (7 sierpnia) odbyło się pierwsze nabożeństwo w intencji zakończenia wojny, odprawiane następnie codziennie przy dużym udziale wiernych. Pyskowicki proboszcz pisał o rosnącej drożyźnie, reglamentowanych towarach i ich braku w tutejszych sklepach: „Wszystko, co niezbędne dla prowadzenia wojny, przejęło wojsko. Narodowi zostało niewiele. Zbliżała się drożyzna i brak żywności. Tym konieczniejsza stała się troska o biednych i rodziny, których członkowie powołani zostali do wojska. Duże znaczenie miały dary bożonarodzeniowe stowarzyszenia św. Wincentego" ${ }^{33}$. Również akcja pomocy żołnierzom na froncie była niejako odpowiedzią na wysyłane do parafii prośby ${ }^{34}$. Wiadomości o zwycięstwach na chwilę polepszyły nastroje mieszkańców, a nagłówki z codziennych gazet: Zwycięski marsz przez Francję; Dziesięć francuskich korpusów pobitych; Twierdza Lille zdobyta; Maubeuge skapitulowało - dawały nawet nadzieję na rychłe zakończenie wojny.

Pierwszą ofiarą wojny z pyskowickiej parafii był 20-letni oficer Helmut Gerlach, który zginął we Francji. W 1915 roku złoto, jakie posiadali u siebie mieszkańcy, zostało przekazane do banku Rzeszy i zastąpione pieniędzmi papierowymi o tych samych nominałach. W komunikatach donoszono, że pieniądze te po wojnie zostaną z powrotem wymienione na monety ze szlachetnego kruszcu. Ale w pewnym momencie zabrakło nawet pieniędzy papierowych, same zaś gminy zaczęły produkować pieniądz zastępczy. Wojna na wielu odcinkach frontu przybrała charakter pozycyjny, a niektórzy żołnierze przyjeżdżali do domu na krótkie urlopy. Wiosną 1915 roku, na specjalny apel papieża Benedykta XV, biskup A. Bertram zarządził przeprowadzenie zbiórki na rzecz głodujących w krajach podbitych przez Niemców, głównie w Polsce, na Rusi i Litwie. Pierwszą taką kolektę zrealizowano w Wielkim Poście 1915 roku, a kolejne w późniejszym terminie, także dla jeńców wojennych ${ }^{35}$. Ks. J. Chrząszcz zapisał na kartach swojej książki to, co widział nie z perspektywy frontowca, ale mieszkańca zwykłego, prowincjonalnego miasteczka: przejeżdżające przez pyskowicką stację pociągi z wojskiem, czasami jednego dnia nawet 80 lub 100, przymusowe rekwizycje koni, bydła, pojawiający się brak żywności: „Przemarsze wojsk miały w sobie coś tajemniczego. Nikt nie wiedział, dokąd właściwie zmierzali żołnierze i gdzie odbywa się bitwa. Poza tym panowała jakaś dziwna cisza"36. W globalnej wojnie prości ludzie odczuwali pewną bezradność. Cisza pod koniec drugiego roku

${ }^{32}$ Tamże.

${ }^{33}$ Tamże, s. 174.

${ }^{34}$ Zob. J. Negwer, Geschichte des Breslauer Domkapitels im Rahmen der Diözesangeschichte vom Beginn des 19. Jahrhunderts bis zum Ende des Zweiten Weltkrieges, K. Engelbert (wyd.), Hildesheim 1964, s. 169-170.

${ }^{35}$ Sammlung für die Notleidenden in den polnischen Gemeinden, „Verordnungen”, (1916) nr 560 (1.03.1916 r.), nr 117.

${ }^{36}$ Zob. Chrząszcz, Historia miast Pyskowice i Toszek, s. 175. 
wojny zamieniła się w ,powszechną tęsknotę za pokojem”37. We wszystkich kościołach odmawiano modlitwę Ojca Świętego Benedykta XV, w której proszono o zakończenie wojny i nastanie pokoju (Oratio pro pace) $)^{38}$.

\section{Tragizm wojny, tęsknota za pokojem}

W trzecim roku wojny dotarła również do Pyskowic wiadomość, że w przyszłości cesarze Wilhelm II i Franciszek Józef zagwarantują niepodległość Polsce. Lecz „największy przyjaciel Niemiec”, jak ks. J. Chrząszcz określał cesarza Franciszka Józefa, zmarł w tymże roku w wieku 86 lat. Zima 1917 roku była bardzo surowa i jeszcze bardziej spotęgowała biedę zarówno wśród żołnierzy na froncie, jak i u pozostałych mieszkańców. Tragizm wojny i jej złowrogie skutki najlepiej oddają te słowa ks. J. Chrząszcza:

Ubodzy nie mieli nic do jedzenia. Z okolic Bytomia przychodziły gromady kobiet, aby na wsi kupić ziemniaki i zboże. Nie tylko bydło, ale nawet pracowite zwierzęta pociągowe musiały być zabijane z powodu braku paszy. Głównym zmartwieniem władz było zaopatrzenie ludności w żywność. Gadanina dotycząca wiadomości od wojskowych poddana została surowym karom. Gazety wzywały myśliwych i mieszkańców wsi posiadających broń do odstrzału wron. Pisano m.in.: „Przy obecnym braku żywności tysiące kilogramów mięsa, które w postaci wron latają bezużytecznie w powietrzu, mogłyby mieć istotne znaczenie dla odżywiania narodu" 39 .

Straszne mrozy trwały od 5 stycznia do 7 marca, a ponieważ zabrakło koni do zwózki węgla, marzli także ludzie bogaci. W kwietniu do wojny przeciwko Niemcom przystąpiły Stany Zjednoczone. Ks. J. Chrząszcz pisał naiwnie, że Niemcy pragnęły rokowań ze stroną przeciwną w sprawie pokoju, lecz ich oferty były odrzucane. Przeprowadzone kolejne zbiórki ubrań i żywności dla żołnierzy były mizerne. Zdawano sobie coraz większą sprawę z tego, jak wielką nędzę cierpieli sami mieszkańcy.

Z wielkim niedowierzaniem ks. J. Chrząszcz przyjął do wiadomości fakt, że 13 marca 1917 roku abdykował w Rosji car Mikołaj II: „Olbrzymie państwo pozostało bez głowy" ${ }^{40}$. Rząd niemiecki poszedł na pewne ustępstwa również względem Kościoła, cofając m.in. zakaz pobytu dla jezuitów, zarządzenia dotyczącego języka używanego w szkole czy też wywłaszczenia najbiedniejszych. Zdawano sobie jednak sprawę z tego, że rząd pragnął w ten sposób jeszcze bardziej związać ze sobą Kościół katolicki i jego wyznawców ${ }^{41}$. Cena za to była ogromna: zaciągi

37 Tamże, s. 176.

${ }^{38}$ Gemeinsames Gebet der ganzen katholischen Christenheit um Frieden, „Verordnungen”, (1915) nr 555 (28.01.1915 r.), nr 26, s. 15-17.

39 Zob. Chrząszcz, Historia miast Pyskowice i Toszek, s. 178.

40 Tamże.

${ }^{41}$ Zob. J. Mandziuk, Historia Kościoła katolickiego na Śląsku, t. 3, cz. 4: 1914-1945, Warszawa 2010, s. 16. 
nowego rekruta ${ }^{42}$ czy też zabór kościelnych dzwonów ${ }^{43}$. Ks. J. Chrząszcz w tym czasie pisał: „Wśród ludności pytanie zasadnicze brzmiało: «Czy masz coś do zjedzenia»? Papierowe pieniądze przyjmowano niechętnie, kwitł handel zamienny, a wraz z nim spekulacja" ${ }^{44}$. W takich nastrojach mieszkańcy weszli w ostatni rok wojny.

\section{Upadek starego systemu}

Rok 1918 przyniósł śmierć cara i jego rodziny, epidemię grypy-hiszpanki, a zachodni front był dokładnie tam, gdzie był na początku wojny. Trzy i pół miliona jeńców pracowało $\mathrm{w}$ niemieckich i śląskich fabrykach. Biskup wrocławski jeszcze na początku wojny prosił duchowieństwo o szczególną opiekę nad nimi. Jak pisał, zgodnie z prośbą papieża: „Ważne jest to, abyśmy wobec wrogów okazali się chrześcijanami” ${ }^{45}$. Kapłanom nakazał odwiedzać obozy, sprawować tam nabożeństwa, nieść pomoc materialną, rozdawać literaturę religijną i pomagać w prowadzeniu korespondencji do rodzin, o ile to było możliwe i na ile zgadzała się na to wojskowa władza.

Ks. J. Chrząszcz pisał na kartach książki o brzemiennym w skutkach 30 października 1918 roku, kiedy to sprzymierzeńcy Niemiec: Turcja, Bułgaria i rozpadająca się Austria, skapitulowały. Dzień ósmego listopada był ostatnim dniem II Rzeszy. Dzień później wydarzył się - w opinii ks. J. Chrząszcza - potworny przewrót. Cesarz abdykował, a władza przeszła w ręce socjaldemokratów. W miastach tworzyły się rady żołnierskie i robotnicze. Miejskie milicje obywatelskie pilnowały na ulicach porządku. Ks. J. Chrząszcz pisał o powracających z frontu 10 milionach upokorzonych żołnierzy, o „rozpętanej agitacji”, w której coraz głośniej pytano, co stanie się ze Śląskiem. Pyskowicki proboszcz daleki był od popierania głoszonych haseł rewolucyjnych i narodowościowych, których osobiście nie pochwalał. Bynajmniej nie chodziło mu o jakieś uporczywe trwanie Ślązaków przy Niemcach. Bolało go bardziej to, że stary porządek legł na jego oczach w gruzach, a nowi przywódcy, którzy się nimi czynili, wzbudzali wśród ludności chaos, podziały i wzbierającą z każdym dniem nienawiść. Takie stanowisko można wywnioskować na podstawie zapisków ks. J. Chrząszcza, opatrzonych datą 23 lutego 1919 roku:

W niedzielę odbyło się w sali hotelu „Germania” imponujące zebranie protestacyjne przeciw polskim knowaniom na Górnym Śląsku... Na adres zgromadzenia narodowego w Weimarze wysłano następujący telegram: „Około 800 mężczyzn i kobiet z Pyskowic, powiat Gliwice, zebranych dzisiaj w hotelu «Germania» niniejszym oświadcza, że pragnie nadal w sposób wolny i nie-

${ }^{42}$ „Niektórzy rodzice mieli po czterech i więcej synów na froncie”. Zob. Chrząszcz, Historia miast Pyskowice i Toszek, s. 179.

${ }^{43}$ „Był to wstrząsający moment, owo rozbijanie dzwonów w piątek 6 lipca [1917 r.], a potem następnego dnia, po uroczystym nabożeństwie, odwiezienie ich do Gliwic na wozie przyozdobionym kwiatami”. Zob. tamże.

${ }^{44}$ Tamże.

${ }^{45}$ „Da $\beta$ wir auch gegen die Feinde uns als Christen erweisen”. Zob. A. Bertram, Pastorale Fürsorge für Kriegsgefangene, „Verordnungen”, (1915) nr 553 (5.01.1915 r.), nr 553, s. 1-2. 
skrępowany posługiwać się swoim językiem ojczystym, wyznawać swoją religię i pozostać jak dotąd w swojej śląskiej ojczyźnie. Zebrani zgłaszają zdecydowany protest przeciw próbom wcielenia Górnego Śląska lub jego części do nowo powstającego państwa polskiego, podjętym przez polskich nacjonalistów. Gwarancje zachowania swojej tożsamości i kultury zebrani widzą jedynie w ramach państwa niemieckiego" 46 .

Ks. J.Chrząszcz bynajmniej nie wszedł do zawiązanego komitetu Wolnego Związku dla Ochrony Górnego Śląska. Niemniej jednak uważał, że tylko tak można uratować stary porządek. Kolejne miesiące przyniosły - zdaniem ks. J. Chrząszcza - nie tyle potrójny zryw wyzwoleńczy Slązaków, co wojnę domową i dalsze podziały wśród ludności. Stary proboszcz, który chciał być ojcem dla wszystkich parafian, pozostał może i osamotniony, i niezrozumiały, ale bynajmniej nie bezczynny. Wybrał stary porządek, ale nie wyrzekł się swoich polskich korzeni. Uważał, że Ślązacy mogą nadal mówić w swojej ojczyźnie po polsku i po niemiecku, i nadal budować wspólny dom. Zapisane słowa jednej z not protestacyjnych pyskowickich mieszczan wobec surowego traktatu pokojowego oddają owe myślenie: „Mieszkańcy sprzeciwiają się szczególnie oddaniu w obce ręce Górnego Śląska, gdzieśmy, zarówno po niemiecku jak i po polsku mówiący obywatele, przez ponad 700 lat razem w pokoju współżyli i pracowali. Od rządu żądamy, aby nie podpisywał tak rujnującego kraj pokoju. Chcemy żyć i umierać jako niemieccy obywatele" 47 .

\section{Zamiast zakończenia. Ks. J. Chrząszcz czlowiekiem schyłkowej epoki}

Analizując pozostawiony przez ks. J.Chrząszcza zapis kronikarski, zupełnie różniący się od jego historycznych tekstów, można powiedzieć, że jest on przede wszystkim analizą wydarzeń i faktów widzianych z perspektywy człowieka wychowanego w duchu posłuszeństwa do władzy. Ten górnośląski historyk - absolwent pruskich szkół, który sam w młodości doświadczył tragedii wewnętrznej walki państwa z Kościołem - boleśnie przeżył tragedię wielkiej wojny z lat 1914-1918. Z frontu do pyskowickiej parafii nie powróciło wielu mężczyzn, a ci, którzy zostali w domach, cierpieli głód i biedę. „Ciężki to był czas - pisał ks. J. Chrząszcz - powietrze drgało od nienawiści i niezgody, a duchowni okazywali się bezsilni" "48. Krytykowana przez niektóre osoby postawa starego proboszcza, któremu zależało na tym, aby ziemi ojczystej nie dotknęły bolesne podziały, nie wynikała bynajmniej z politycznego wyrachowania. Trzeba w tymże przypadku bardziej dostrzec jego pasterską troskę o jedność jego górnośląskich ziomków. On sam jako człowiek mijającej epoki był złudnego przekonania, że gdyby przetrwały monarchie, to być może w jakiś inny sposób sprostano by żądaniom Ślązaków o prawo do mowy polskiej i ich samostanowienia. W tymże przypadku podzielał stanowisko nie tylko swojego biskupa, ale i biskupów wszystkich polskich diecezji w Cesarstwie Niemieckim, którzy z dezaprobatą patrzeli na burzących porzą-

\footnotetext{
${ }^{46}$ Zob. Chrząszcz, Historia miast Pyskowice i Toszek, s. 183.

${ }^{47}$ Tamże, s. 183-184.

${ }^{48}$ Tamże, s. 189.
} 
dek społeczny rewolucjonistów: „Będziemy ustawicznie gotowi bronić tak ołtarza, jak i tronu... Nie możemy się przyłączyć do tych, którzy postrzegają państwo jako praźródło wszelkiego prawa i przyznają mu nieograniczoną pełnię władzy"49.

Czy w tych trudnych dniach wojny można było być spokojnie duszpasterzującym proboszczem, zajmującym się w wolnych chwilach historią? Czy nie na wyrost stawiane są zarzuty o stronniczość i rzekome sprzyjanie niemieckości? Trudno to sobie wyobrazić, śledząc historię późniejszego zrywu powstańczego i aktywnego zaangażowania duchowieństwa katolickiego po jednej i po drugiej stronie. Ks. J. Chrząszcz bynajmniej nie pisał o swojej działalności politycznej w tymże czasie. Bliższa mu była postawa pracy ponad podziałami. Jeden z zapisków z trudnych dni 1920 roku oddaje chyba tę jego postawę najbardziej:

3 czerwca przypadało Boże Ciało. Na długo przedtem rozszerzyła się pogłoska, jakoby Polacy zamierzali zakłócić uroczystość, zabronić łacińskiego śpiewu, a na jego miejsce wprowadzić śpiew polski. Mówiono, że z Łubia i Kopienicy pojawią się ludzie, którzy wymuszą polski śpiew. Dzień był deszczowy. Proboszcz oświadczył: „Niech będzie, co chce; procesja się odbędzie”. I odbyła się szczęśliwie, z dużym udziałem wiernych. Padał drobny deszczyk ${ }^{50}$.

Sam ks. J. Chrząszcz jako zwolennik mijającej epoki z trudem mógł zaakceptować rządy socjaldemokratów i towarzyszący temu chaos polityczny, społeczny i gospodarczy. Ceną trwających w latach 1918-1922 braterskich sporów na Górnym Śląsku były tysiące zabitych i rannych oraz podział Górnego Śląska. Śląscy powstańcy czuli, że tylko w tak spektakularny sposób doprowadzą do połączenia Górnego Śląska z odrodzoną Polską. Ks. J. Chrząszcz był innego przekonania, a przede wszystkim był przeciwnikiem zbrojnej konfrontacji, w imię zachowania pokoju i jedności. Zmuszony do wyboru, wybrał pozostanie Górnego Śląska w państwie niemieckim, jak większość jego pyskowickich parafian. Nigdy jednak nie wyrzekł się tego, że jest synem tej ziemi, mówiącym po polsku i po niemiecku. I jako nadal urzędujący proboszcz, a nie tylko historyk, angażował się w dzieło budowy powojennego ładu na Śląsku. Był to czas głodu, szalejącej inflacji i niepokojów społecznych. On sam zaś pozostawił na ostatnich kartach analizowanej książki ważne zdanie, powtarzane w tamtym czasie przez wielu Ślązaków: „Od teraz trzeba zacząć wszystko od początku"si.

${ }^{49}$ Hirtenschreiben des deutschen Episkopats über die kirchenpolitischen Forderungen und Aufgaben der Gegenwart vom 1. November 1917. Cyt. za: E.R. Huber, W. Huber, Staat und Kirche im 19. und 20. Jahrhundert, t. III: Staat und Kirche von der Beilegung des Kulturkampfes bis zum Ende des Ersten Weltkrieges, Berlin 1983, s. 519.

${ }^{50}$ Zob. Chrząszcz, Historia miast Pyskowice i Toszek, s. 186.

${ }^{51}$ Tamże, s. 189. 


\section{BIBLIOGRAFIA}

\section{Opracowania}

Bertram Adolf, Pastorale Fürsorge für Kriegsgefangene, „Verordnungen”, (1915) nr 553 (05.01.1915 r.), nr 553, s. 1-2.

Bertram Adolf, Kirchliche Begehung des Geburtstages des Kaisers, „Verordnungen”, (1915) nr 554 (18.01.1915 r.), s. 9.

Bertram Adolf, Kreuzeskraft und Kreuzeslehren in der Kriegszeit (Fastenhirtenbrief), „Verordnungen”, (1916) nr 576 (02.02.1916 r.), s. 55.

Bertram Adolf, De vita clericali sacerdotum auctoritate militari conscriptorum „Verordnungen", (1916) nr 580 (01.03.1916 r.), s. 28-29.

Chrząszcz Johannes, Geschichte der Städte Peiskretscham und Tost sowie des Toster Kreises in Oberschlesien, Peiskretscham 1900; wyd. 2 Peiskretscham 1927.

Chrząszcz Johannes, Historia miast Pyskowice i Toszek, Pyskowice 1994; wyd. 2 Gliwice 2009.

Dola Kazimierz, Chrzaszcz Jan, w: Encyklopedia katolicka, t. 3, red. F. Gryglewicz, Lublin 1979, k. 346.

Gemeinsames Gebet der ganzen katholischen Christenheit um Frieden, „Verordnungen” 1915, nr 555 (28.01.1915 r.), nr 26, s. 15-17.

Giela Joachim, Biographisch-bibliographische Studien zu dem oberschlesischen Pfarrer und Historiker Johannes Chrzaszcz, „Oberschlesisches Jahrbuch”, 16-17 (2000/2001) s. $91-128$

Górecki Piotr, Dziewiętnasto- $i$ dwudziestowieczne wydarzenia na Górnym Ślasku w twórczości pisarskiej ks. Johannesa Chrzaszcza. Wprowadzenie do drugiego polskiego wydania ksiażki „Historia miast Pyskowice i Toszek”, w: J. Chrząszcz, Historia miast Pyskowice i Toszek, wyd. 2, Gliwice 2009, s. 9-11.

Hinkel Sascha, Adolf Kardinal Bertram. Kirchenpolitik in Kaiserreich und Weimarer Republik (Veröffentlichungen der Kommission für Zeitgeschichte, seria B: Forschungen, t. 117), Paderborn-München-Wien-Zürich 2007.

Huber Ernst Rudolf, Huber Wolfgang, Staat und Kirche im 19. und 20. Jahrhundert. Dokumente zur Geschichte des deutschen Staatskirchenrechts, t. 3: Staat und Kirche von der Beilegung des Kulturkampfes bis zum Ende des Ersten Weltkrieges, Berlin 1983.

Kowalczyk Halina, Chrzaszcz Jan (1857-1928), w: Stownik biograficzny katolickiego duchowieństwa ślaskiego XIX i XX wieku, red. M. Pater, Katowice 1996, s. 68-69.

Mandziuk Józef, Chrząszcz Jan, w: Słownik polskich teologów katolickich 1918-1981, red. L. Grzebień, t. 5, Warszawa 1983, s. 216-221.

Mandziuk Józef, Historia Kościoła katolickiego na Ślasku, t. 3: Czasy nowożytne, cz. 3: 1887-1914, Warszawa 2009.

Mandziuk Józef, Historia Kościoła katolickiego na Śląsku, t. 3: Czasy nowożytne, cz. 4: 1914-1945, Warszawa 2010.

Negwer Josef, Geschichte des Breslauer Domkapitels im Rahmen der Diözesangeschichte vom Beginn des 19. Jahrhunderts bis zum Ende des Zweiten Weltkrieges, K. Engelbert (wyd.), Hildesheim 1964.

Nowack Alfons, Dem Andenken an Dr. Johannes Chrzaszcz, „Der Oberschlesier”, 13 (1931) nr 5, s. 284, 286

Nowack Alfons, Lebensbilder schlesischer Priester, Breslau 1939.

Ogrodziński Wincenty, Chrzaszcz Jan, w: Polski słownik biograficzny, t. 3, red. W. Konopczyński, Kraków 1937, s. 476. 
Ogrodziński Wincenty, Dzieje piśmiennictwa śląskiego, do druku przyg. L. Brożek, Z. Hierowski, Katowice 1965.

Piela Michał, Ksiażę kardynat dr Adolf Johannes Bertram jako przewodniczacy Konferencji Episkopatu Niemiec (Fuldajskiej Konferencji Biskupów) w latach 1920-1945, cz. 1: Do końca istnienia Republiki Weimarskiej, Wrocław 2013.

Rosenbaum Sebastian, „Doctor inefabilis”. Ksiadz Johannes Chrzaszcz i jego miejsce w spuściźnie kulturowej Górnego Śląska, w: J. Chrząszcz, ,, Meminisse iuvat”. Wybór pism, Gliwice 2018, s. 24-27

Sammlung für die Notleidenden in den polnischen Gemeinden, „Verordnungen”, (1916) nr 560 (1.03.1916 r.), nr 117.

Szramek Emil, Ks. dr Jan Chrzaszcz. Wspomnienie pośmiertne, „Roczniki Towarzystwa Przyjaciół Nauk na Śląsku", 1 (1929) s. 258-261.

\title{
THE NOTES OF FATHER JOHANNES CHRZĄSZCZ ABOUT WORLD WAR I. THE FIGURE OF UPPER SILESIAN HISTORIAN TO COMMEMORATE THE 90TH ANNIVERSARY OF HIS DEATH
}

\begin{abstract}
Summary
The 90th anniversary of Fr. Johannes Chrząszcz's death held in 2018 is a good opportunity to bring the figure of this Upper Silesian priest to a wider circle of readers. Fr. Piotr Górecki in his article presents the figure of Fr. Chrząszcz mentioning the most important events of his priestly life and bringing closer his scientific activity, numbering 172 works, mainly from the history of Upper Silesia. On the basis of the 100th anniversary of the ending of the World War I Górecki first of all reflects on the attitude of the Silesian priest towards secular power. The chronicle records made by Fr. Chrząszcz in the book about two Upper Silesian towns Toszek and Pyskowice are the source of research. The reading of already older at that time priest's writings reveals to us the great dilemmas faced by him and his contemporary priests. It seems that his loyal attitude was to avoid any social upheavals and revolts, even at the price of uncompromising loyalty to the secular power and maintenance of "alliance of the altar and the throne" brought out through the ages. This attitude characterised also a large group of priests from different parts of Poland occupied by the invaders. The discourse confirms the thesis that both Fr. Chrzaszcz as well as some of his contemporary Church representatives were a kind of epigones of the passing era. They did not notice the dawn of a new era and the birth of a new order, which brought the rebirth of Poland and the new hope for Silesia. This is the reason why the attitude of Fr. Chrząszcz was omitted by his descendants in their historical works. It is a pity, because the awareness of Fr. Chrząszcz's scientific legacy may help to get a better understanding of Silesian history, as well as to realize rich multicultural heritage associated with Silesians for centuries.
\end{abstract}

Key words: father Johannes (Jan) Chrząszcz; history of Church in Silesia; Upper Silesia; world war I 